\title{
Promoting Ghana's traditional cultural aesthetics in Ghana's most beautiful reality television show ${ }^{1}$
}

\author{
Albert Dennis \\ Assistant Lecturer \\ Department of Theatre and Film Studies \\ University of Cape Coast, Ghana \\ E-mail: adennis@ucc.edu.gh
}

Submitted: August 11, 2017 / Accepted: October 10, 2018 / Published: December 3, 2018

\begin{abstract}
In recent times, the mass media in Ghana have come under heavy attack for what is often considered to be their suffocating antisocial content. Cultural nationalists in Ghana have expressed their aversion to the hegemonic representation of Western and other non-Ghanaian cultures, much to the detriment of local ones. However, there are a few mass media programmes that attempt to promote aspects of Ghanaian culture. Using Ghana's most beautiful (GMB), a reality show produced by a privately-owned Ghanaian television channel, TV3, this paper attempts a critique of the representational motives of the programme vis-à-vis the nexus of foreign content and locally relevant ones. The paper undertakes an analysis of the 2013 edition of the programme and argues that, whilst GMB can be commended for offering a fair playing field for all the contestants in the show, it still exhibits traits of cultural hegemony and consumerism.
\end{abstract}

Keywords: culture, pageantry, hegemony, mass media, reality show

\section{Introduction}

Globalisation and technological advancements in the twentieth and twenty first centuries have brought radical transformations into people's cultures and traditions (Mott, 2004; Panopio \& Santico-Rolda, 2006; Ferraro, 2008) and dictated a lopsided transfer of culture in favour of hegemonic global relationships that often promote Western culture against other ways of life. These transformations have often only satisfied contemporary hegemonic and consumerist lifestyles. Some modifications of

\footnotetext{
${ }^{1}$ This work has been possible by the kind courtesy of management of TV3, organizers of Ghana's most beautiful. I am also grateful to the contestants of the 2013 edition of Ghana's most beautiful.
} 
culture can improve social habits and living standards, yet the same transformations can also promote lifestyles which can be perceived as offensive, precarious and licentious and therefore likely to impact negatively the cultural sensibilities of many and portray a false representation of culture. Undoubtedly, every community is unique, and what is considered a taboo in one may be the norm in other. However, in Ghana, as in many other countries particularly in Africa, the beauty of the national society can be experienced in the diversity of cultural expression and traditional practices. In Ghana, every ethnic group strives to uphold its rich indigenous culture and represent what is the best of its existence. This is in spite of the undeniable influences of foreign cultures, instituted through many years of colonial governance and education, whose legacy has persisted after over half a century of national independence. This colonial and neo-colonial legacy combines with the unfair distribution of information and culture across the globe to maintain a hegemonic cultural imperialist system of global relationships that favours the Euro-American civilisation.

The result of this relationship is the gradual erosion of local traditions, and their replacement by television programmes, video games, social ways of dressing, speaking and relating, which are alien to the cultures of most communities. For example, nowadays, one hardly sees Ghanaian children enjoying traditional games, such as pempenaa ${ }^{1}$ ampe $^{2}$ and kabadzim ${ }^{3}$. These were games that had meaning and inconspicuously taught the children the moral values of their societies. Such values included tolerance, forgiveness, team spirit, alertness and social harmony. In the traditional Ghanaian society it was not customarily acceptable to use one's left hand in waving to people or in performing some vital activities in public

\footnotetext{
1 pempenaa is a traditional Akan game where a number of children sit together with their legs stretched forward with a leader. The leader passes his/her hands over their legs and says pempenaa as the rest respond nanaa. The leader points the figures at the legs of the children as he/she (leader) sings along. The one on whose legs the song ends becomes free and exits.

2 ampe is a traditional Akan game which involves two or more females. In its simplest term, members clap their hands to a particular rhythm as they jump simultaneously and bring a leg forward before placing both feet on the ground. Each person selects a particular leg that will score points for him or her as they play accordingly and count their points aloud.

3 kabadzim is a traditional Akan game performed in a big rectangular space.
} 
when the right hand was free. Whilst the Euro-modernist would perceive this as superstitious, most Ghanaian cultures saw that as disrespect for various reasons, including religion and hygiene.

Similarly, many Ghanaian societies have lost the beauty and richness of the ceremonies and rituals that accompanied events such as naming ceremonies and marriage rites. These were events that had history, the essence of being and the values of the society embedded in them. These have largely been replaced by so-called modern fads, practices and styles which are mostly Eurocentric.

It was the seeming national need to refocus attention on indigenous culture, albeit in its modernist and syncretic form, that GMB was created and institutionalised (Akuoku, 2015). To understand the context within which this programme operates and to undertake a contextualized analysis of the programme, one needs to clarify certain key concepts, which can serve as guiding posts for better comprehension.

\section{Theoretical and conceptual framework}

The term 'culture' is often used to refer to the way a group of people lives and that which makes them distinct from others. The Cultural policy of Ghana (2004) defines culture as;

the totality of the way of life evolved by our people through experience and reflection in the attempt to fashion a harmonious co-existence with our environment. This culture is dynamic and gives order and meaning to the social, political, economic, aesthetic and religious practices of our people. Our culture also gives us our distinct identity as a people. (pp. 2-3).

This definition presents a homogeneous view of culture in Ghana, and describes it, not in abstract terms, but as related to a real and meaningful existence. Similarly, Gyekye (1998) defines culture as "the entire life of a people: their morals, religious beliefs, social structures, political and educational system, form of music and dance and all other products of their creative spirit" (p. xiii). Gyekye's illumination of culture seeks to unearth the constituents 
of culture and outline's the ingredients which make one community unique from the other. One element which Gyekye's definition of culture encapsulates and is very relevant in this essay is the educational system. This is because an educational system based on a curriculum which reflects the culture of the people ultimately helps to transmit their customs from one generation to the other. We will see later how GMB attempts to offer cultural education on the platform of a television reality show, and demonstrate a sense of national cohesion in spite of diversity.

Once a people identify themselves with a particular lifestyle, they tend to protect it and coin moral values aimed at making them more united and nationalistic. Botchway (2008) observes that, "people belonging to diverse ethnic and national groups have always, in one way or the other, tended to be nationalistic as they try to protect the cultural, economic, political and social interest of their ethnicity and culture" ( p. 169). Without a doubt, when a people become nationalistic, they foster development for the reason that they all share in the same norms of the community, and share a common understanding of their practices that promote development. This stems from a shared ideological orientation that allows for common aspirations and actions.

Ideology is an important concept for appreciating the ways in which GMB tries to represent the general in a unified and communal sense. Hall (1996) has described ideology as "the mental frameworks - the languages, the concepts, categories, imagery of thought, and the systems of representation - with different classes and social groups deploy in order to make sense of, define, examine and render intelligible the way society works" (Hall, cited in Morley \& Chen ed., 1996, p. 26).

Hall (1996) problematises ideology as different ideas gripping the minds of masses, and by so doing becomes "a "material force"' (p. 27). He argues that ideology, from a political perspective, reveals how a set of ideas may come to dominate the social thinking of a people at a point in their history, in a Gramscian approach. This domineering set of ideas tends to unite from within 
and holds society together. However, Hall (1996) has also noted that there is a problem of hegemony in which a dominant cultural order imposes itself on the rest and constantly rearticulates certain dominant structures of meaning. For example, it will be seen that in GMB, the contestant who garners the most votes by the public, through arbitrary commercial system of SMS messaging, is the most beautiful, physically fit and intellectually sophisticated.

In the words of Schirato and Yell (2000), culture is "the totality of ... practices and systems" (p. 1), while, Maison (2007) argues, when appreciated within a Ghanaian context, that it embodies the means, the "vehicles designed to bring out the best of an individual's humanity within a cultural space" ( p. 29). It will be seen, in this paper, how GMB positions itself to serve as a vehicle for practicing a wide variety of cultures for uplifting the cultural values of both individuals and societies.

Moreover, GMB presents itself as a museum or repository for intangible culture. Over the years, various approaches were employed to salvage, preserve and pass on Ghanaian culture from one generation to the other. Notable among such interventions was the setting up of museums and the recognition of traditional festivals and durbars. The mass media, such as radio and television were also used to document, transmit, project and protect various aspects of culture in the country, and to "reinforce and support values, habits, traditions, and systems." (Shafeek, cited in Adesi and Odi, 2013, p. 392). GMB appears to complement these efforts, most of which have fallen by the wayside and replaced by foreign content productions, such as Latin-American telenovelas and Asian soap operas.

The paper attempts a cultural reading of GMB in order to explore the practices and systems that are often on display through pageantry, clothes, performance, music and dance, and rhetoric. It will be interesting to observe how GMB offers a representation of the heterogeneous cultures of Ghana and presents them as if they were one and the same thing. However, the argument will be that GMB is informed by the same cultural and economic hegemonies 
that it seeks to contest, as the entire competition is framed within a modernist setting and dictated largely by the commercial interests of sponsors whose names and logos are widely displayed during the performance of GMB.

\section{Pageantry and Ghanaian culture}

Pageantry is an integral part of Ghana's popular culture. Beauty pageants form a significant part of many traditional festivities celebrations. Oral traditions about traditional festivals in some communities reveal that maidens often volunteered to dramatize some aspects of their society's culture and traditions. This did not only enhance the beauty and entertainment value of the occasion, but also served as a knowledge test of the moral values and cultural practices of the society. The most knowledgeable contestant was usually adjudged the most 'beautiful' woman and celebrated. The beauty that was celebrated was therefore not merely physiological but also intellectual. Many annual customary festivals in Ghana now have beauty pageants as part of the celebrations.

Other longstanding cultural ceremonies such as puberty rites, for example bragoro $^{4}$ among the Akans and dipo ${ }^{5}$ among the Krobos, also allow young women to demonstrate their physical and intellectual qualities, and exhibit the best of their traditions. It can be argued that a contemporary beauty pageant like the GMB draws inspiration from these old and traditional showpieces.

\section{Methodology}

The 2013 edition of GMB was selected for analysis in this work. This was because the spectacle at the launch of this edition in Kumasi suggested that the 2013 edition of the reality show would be full of cultural aesthetics of the Ghanaian tradition. This was evident in the rich cultural display of dances, clothing and the large number of chiefs who attended the launch. This was different from the 2012 launch of the show hence the selection of the 2013 edition for analysis. The researcher watched the entire telecast of

\footnotetext{
4 bragoro is the name of initiatory puberty rites among the Akans of Ghana.

5 dipo is the name of rites of passage puberty rites among the Krobos of Ghana.
} 
the 2013 edition of GMB for the thirteen weeks that it was telecast and obtained some information relevant to the development of this paper. He obtained the video recordings of the 2013 edition of GMB from TV3 for analysis.

The study involved the analysis of all the episodes of the 2013 edition of the show. Recorded versions of previous programmes of GMB were accessed from the archives of TV3 for additional analysis. Interviews were conducted with some key persons among the producers of GMB. It was difficult to reach all the contestants for the 2013 edition of GMB. However, five out of the ten contestants were interviewed. Even though they provided relevant information of a general nature, this cannot be representative of the rest.

\section{Background to the 2013 edition of GMB}

The 2013 GMB started with auditions in all the ten administrative regions of Ghana. A female contestant was selected from each region to represent that area. The opening ceremony of the competition took place in Kumasi, Ghana's second largest city. Many traditional rulers were at the ceremony to validate it as an important cultural event with the potential of heralding an important national competition. Nana Wiafe Akenten IV, the chief of Ofinso, chaired the ceremony. The thirteen-week competition itself was held at TV 3's Studio B. The finale took place at the Accra International Conference Centre, and was telecast live on TV3.

For thirteen weeks the ten contestants displayed their knowledge and skills in traditional and contemporary Ghanaian culture through competitive speeches and performances. Two judges, a man and woman, commented on each contestant's performance. Both live audiences and television viewers contributed to the judgment by voting for their preferred candidates through short message service (SMS) of MTN, Tigo, Airtel and Vodafone Telecommunication Companies.

As part of efforts to give GMB a national appeal, each contestant was expected, at a point in time, to perform a speech, dance or ritual from a region different from hers. The shortlisting of 
contestants began after the preliminary stages and was based on the SMS count. The contestant, who had the lowest number of votes and did not impress the judges enough, was eliminated.

As was the norm, GMB 2013 started with the contestants offering an overview of their respective regions. This information usually included tourist sites, major festivals and the main occupations of the people. They also addressed key issues affecting development in their regions and, in some cases, dramatized them for audience appreciation. Among some of the key issues discussed in 2013 were the challenges of acquiring land in Ghana, the need to patronize made-in-Ghana products, the negative effects of illegal mining, violence against women and the quest for interregional cohesion. The ostensible idea was always to promote national unity. Ultimately, the one who was crowned Ghana's most beautiful embarked on a sponsored social impact project of her choice.

\section{The cultural context of GMB}

There is a wide variety of cultural elements that are integral to GMB. Because the programme needs to pass off as a credible representation of the best of Ghanaian culture, albeit in its diverse forms, GMB strives to depict various cultural and aesthetic motifs that will be easily recognized by audiences. At the same time, GMB consciously depicts the dynamism of culture, particularly as it is influenced by so-called modern ways of living. One of the obvious Ghanaian traditional cultural aesthetics that GMB insists upon is the use of traditional names by contestants.

\section{Traditional names in GMB}

Names within the Ghanaian culture are not only intended for identification, but often carry social and moral meanings. In recent times, despite the fact that many Ghanaians carry non-Ghanaian names, for example European and Arabic names, some families have resorted to giving only Ghanaian names to their children. In recognition of the importance of indigenous names, the contestants in GMB dropped their so-called Christian or Islamic names in favour of traditional ones. 
Ghanaian names, when given at birth, are often informed by circumstances surrounding the birth of the person. As Sarpong (1974) has noted, "the manner of giving or acquiring names is traditionally well regulated in the various societies of Ghana" (p. 88). He explains that names in the Ghanaian context can point to one's ethnic origin, reveal some historical events, or reveal a person's status or position.

For example, according to Mawulolo Gharbin, a lecturer in the Department of Theatre and Film Studies at the University of Cape Coast, in Ghana, his grandmother who was very sick miraculously got healed on the day that he was born. He was therefore named Mawulolo, which in the Ewe language (spoken mainly in Ghana and Togo), means God is great. Among the Akan- speaking communities, a child born on a particular day of the week normally assumes the name that comes with the day. For example, a girl born on Saturday is called Ama whilst a boy born on that same day is Kwame. Since the colonial period, the taste for Anglicized names has been seen as more appropriate and desirable because of their Eurocentric and Western identifications, and their assumption of a higher social status than traditional African names. When a traditional name is adopted by some Ghanaians, it is often a response to an Afrocentric perception of one's personal identity.

Mary Akosua Serwaa Owusu, a senior lecturer in the Department of History, University of Cape Coast, recounts how her local Ghanaian name was modified by the addition of a "Christian" name. She writes that, "my headmistress, Sister Sollamen, being unhappy about my name, (Akosua Serwaa) decided that since I was a baptised Catholic I should add my baptismal name Mary to my name... before she registered me for "A" Levels" (Owusu, 2007, p. 97). This was contrary to her father's wish to have his children known only by their African names.

In recognition of the importance of indigenous names, a famous Ghanaian dramatist, Mohammed Ben Abdallah, projects African culture by assigning local names to his Ghanaian characters in his Abibigoro (plays of Africans). For example, in The witch of 
Mopti (1989), some of the characters are called Nii Sai, Nii Kwei and Osabutey, all representing the Ga ethnic group in Ghana. Others such as Adowa and Kofi Onny represent the Akans while Dzifa and Togbi represent the Ewes.

Similarly, GMB prefers that its contestants bear traditional names as a sign of cultural relevance, for national cohesion, and as a means of advocating for the popularization of traditional Ghanaian names in Ghana. Therefore, in 2013, the ladies had the following names: Deli from the Upper West region; Akua, Ashanti region; Poka, Upper East; Bubune, Volta region; Konadu, Brong Ahafo; Ama, Western region; Abena, Central region; Dede, Greater Accra; Safoa, Eastern region; and Kadi, Northern region. Whilst these names were interesting, particularly for the fact that they all seemed averagely short to allow for easy texting on SMS, each contestant also wore clothes that depicted their cultural origins or traditional affiliations as a complement to their names.

\section{Clothing in GMB}

Costumes generally convey information about the culture and identity of an individual in a non-verbal way (Lurie, 1981; Kwakye-Oppong, 2011; Dennis, 2014). In a lecture delivered in 2007, Anyaoku cited Robert Calderisi, a former International Monetary Fund official, who described the image of Africans at an international gathering, thus, "if not for their colourful national dress at conferences, Africans would scarcely be noted on the world's stage" (Anyaoku, 2007, p. 6). I will argue that, whilst Calderisi's statement was casual and condescending, it must have stemmed from his ignorance of the symbolism in traditional African attires.

My argument is informed by Sarpong's (1974) observation that some "of the commonest media of expressing Ghanaian symbolic art is the cloth" (p. 102). A closer and more discerning observation of Africans at such international gatherings will reveal symbolic art within which are ingrained philosophical and moral messages.

In pursuant of this non-verbal and symbolic means of communication, the contestants of GMB used colourful Ghanaian 
kente, wax prints, and other traditionally woven fabrics to construct their costumes in symbolic patterns and contemporary styles. Wax prints have particularly become important in this process. In spite of their foreign origins, they have been adopted as part of contemporary Ghanaian culture, and are used in various traditional contexts such as marriage, birth and funeral rites.

Gavor and Dennis (2013) have argued that many Ghanaians now perceive the wax print as "African cloth" and when used to construct garments, are branded "African wear". This "African flavor" arises from the various artistic expressions or motifs printed onto the fabric. Additionally, the local names and inscriptions often printed at the selvedge of the cloth symbolize the Africanization of the wax print and portray the social and moral values of the society (p.3).

GMB makes an effort to promote the use of locally made garments that are designed in local flavours as a means of communicating "Ghanaianess". In the 2013 edition of GMB, all the contestants wore various styles of dresses constructed with Africa wax print produced in Ghana for the launch in Kumasi. In all the episodes held at Studio B at TV 3, contestants were predominantly seen in the African wax print. It is of interest to note that in 2006 the President of Ghana, John Agyekum Kuffour, declared Fridays for the wearing of traditional made in Ghana clothes. He was trying to promote Ghanaian identity through the wearing of indigenous clothes. However, whilst this was a brave initiative, the author will argue that it did not go far enough to contest the Eurocentric fashion taste and appearance of most people in Ghana, especially government officials.

In his article 'Our leaders must dress like Ghanaians' Asare (2003) notes that, "the dressing of some... government functionaries at state and international functions does not advertise the country in any way" (p. 6). This is because many government officials prefer wearing imported European suits at the expense of locally made clothes. Asare cautions that "by the time our current 
leaders realize the usefulness of the Ghanaian $f u g u^{6}$, batakari ${ }^{7}$ and $k_{e n t e}^{8}$, they would have lost their significance (sic)" (p. 6).

It is to promote Ghanaian identity through clothes that GMB contestants are required to perform wearing decent traditional costumes. Unlike other beauty pageants, informed by Western concepts of beauty and feminine exhibitionism, where contestants were often required to appear semi-nude for the voyeuristic delight of audiences, GMB contestants were fully clothed in costumes designed in unique Ghanaian styles. This was based on the cultural sensibilities of Ghanaians which did not easily allow a woman to expose certain parts of her body for public view. Among the Akans, a young adult woman would usually be addressed as 'akatasia'. This is the message GMB attempts to communicate.

However, Western influences on contemporary Ghanaian youth have eroded this endogenous philosophy and outlook on life. It is now common to see men and women wearing clothes and intentionally exposing ample portions of their breasts, bellies and buttocks. Others wear very tight clothes in order to amplify their figure. Apart from the health hazards, for example the prevention of the human skin from breathing that is easily associated with this socalled modern way of dressing, it can be argued that it constitutes an affront to local cultural norms on decency and traditions of Ghanaians, and GMB appears opposed to this contemporary popular culture.

However, while GMB strives to be culturally relevant and correct, it also falters occasionally in the presentation of cultural elements, such as its incorporation of modernist trends that seem to conflict with the traditional, rather than complement it. The ways in which the contemporary and the traditional appear contradictory within the syncretic presentations, undermine the essence of promoting an Afrocentric identity.

6 fugu, as noted by Essel \& Amissah (2015), refers to a variety of loose garments sewn from strips of cloth woven on traditional looms in Northern Ghana.

7 batakari, as noted by Essel \& Amissah (2015), consists of a flowing outer gown, long sleeve inner robe and a pair of trousers collectively referred to as a three-piece wear.

8 kente is a rich colourful expensive cloth which is hand-woven and is worn during special occasions. 9 akatasia refers to a virtuous young lady who is decently dressed and modest in her dispositions. 
For example, in 2013, Konadu and Bubune who represented the Brong Ahafo and Volta regions respectively appeared at the grand finale dressed as Ohemmaa and Mamaga (female rulers) respectively but displayed long brightly nail attachments polished red. Their faces were also decked with pronounced make-up. These additions to the female ruler's attire are alien to the real traditional practice, and would certainly have raised some eye-brows among members of royalty in the auditorium.

Moreover, during the thirteenth week of the programme, a short biographical documentary about each contestant was shown. In these short films, some of the ladies could be seen semi-nude, wearing non-African dresses suggesting that they appeared fully clothed only for the competition, while in real life, they did not abide by the same values that they promoted on stage. Such appearances have the potential to undermine all the efforts to reverse the perceived cultural alienation of many young Ghanaians, who mostly neglect their traditional arts for foreign ones, such as music and dance.

\section{Music and dance in GMB}

Music and dance were predominant in the performances because of the important role that they play in Ghanaian societies. Amlor (2008) has noted that, "Africans strongly believe that music and life are inseparable. Hardly would members of a traditional African society organize any social event without music", (p. 141). Similarly, De Lerma (1970) has argued that, "nothing is done in an African society without music... one is born to music, cries to music, plays to music, works to music, is initiated in to music, is married to music and dies to music" ( p. 81).

GMB contestants usually sing indigenous songs such as lullabies, war songs, songs for puberty rites, and dirges. Each contestant would explain the rationale, historical background and the importance of their song and performance, based on research they would have conducted in their respective communities.

In Ghana, one would hardly find any kind of performance that is not accompanied by singing or some other form of music. 
Activities such as communal weeding on farms, fishing and worshiping are often driven by songs. This is an integral part of most cultures in Ghana, and it is transmitted from generation to generation. This is because music, as Allan (1964) puts it, "is a vehicle of history, myth and legends. It points up the continuity of culture through its transmission of education... it contributes to the stability of culture" (p. 223).

Some Ghanaian musicians such as Agya Koo Nimo, Bob Cole, Paa Bobo and Kwasi Ampofo Adjei craft their songs around moral values, historical information and other socially educative elements. While acknowledging that some contemporary songs in Ghana are didactic in nature, it is regrettable to note that the most of contemporary popular music in Ghana is imitative and thrives on frivolity and profanity. No wonder Botchway (2007) argues that,

Observing the trend of life on our campuses, particularly the tertiary ones, there is the weird impression that Ghana is moving away from its own history and culture.... The songs mostly preferred and played by the present younger generation are American rap... indication of western cultural imperialism. (p. 225)

Apart from music, dance forms an integral part of people's lives in Ghana. Various dance forms define the ethnicity of a people through the expression of shared history, experiences, their moral philosophies and outlook on life. Activities such as naming ceremonies, festivals, religious ceremonies, and marriage ceremonies are often replete with dancing. Often these dance performances are informed by the ideological and artistic tendencies of the people.

As Ufford (2010) has noted, "dance is shaped by the values, attitudes and beliefs of the people who compose its 'host' society: It depends on their feeling, thinking, and dynamics, in their combination and consequent form and style and do not exist apart from the human behaviour process which produces them" (p. 124). A variety of dance forms are regularly exhibited in GMB by contestants, exploring their aesthetic and utilitarian values. 
The dimensions of creativity in the various dance movements are achieved as a result of a comprehensive research into the philosophical underpinnings embedded in them. Sunday (2010) notes that, "for a dance performance to achieve...emotional and auditory appreciation, the dancers and the dance performance must... display a high level of artistry in both dance movements in space and timing (sic)" (p. 111).

Beyond the entertainment and aesthetic components, dance also tells the history of a people through its movements in a nonverbal communicative way. As Flolu (2009) explains,

Dance is a physical manifestation of thinking and expression of ideas and feelings. It is a way of knowing and communicating.... Through dance it is possible for children to learn about the history and life of people of different ethnic origins, their customs, their music, their celebration, their world view, in fact their human endeavor. (p. 61)

The challenge that GMB faces in the performance of Ghanaian traditional dances, is that, technically, when a dance piece is taken from its original space to a different one, it loses its originality. In the case of GMB, once contestants performed a particular dance on the proscenium stage and not in the round within the community from which it originated, it tends to lose the philosophical underpinnings that shape its being. The proscenium stage also detracts from the aesthetics of the round space, because the dancer now has to face only one direction, that is, towards the audience. She is therefore restricted from engaging in some of the intricate indigenous movements dictated by audiences or other dancers in a circular formation.

The proscenium stage also offers excessive space for the single dancer. This is a challenge to the performers, since most Ghanaian dances are either performed in pairs or in groups. The single dancer is therefore not able to represent adequately the beauty of the dance. Contestants also have a limited time to be on stage, and are therefore unable to deliver the dances to their 
fullest aesthetic values. This eventually requires a revised and choreographed version of the original dance. Some of the dances performed on the proscenium stage in the round include bamaya by Konadu and adzogbo by Akua. Moreover, there is only one set of drummers who are required to provide the drum music for all the dances. Unfortunately, the band often fails to render some of the dance music in their original finesse.

\section{Language in GMB}

The final cultural component of GMB that I wish to examine, which complements the preceding arguments, has to do with the use of language. Whilst clothes, music and dance can identify people according to their ethnicity, language goes beyond that to give people a sense of belonging, or of exclusion, whichever the case may be (Ekom, 2013). Language has always been the most important means through which people communicate their shared experiences. Ekom (2013) argues that the expression of the various values and aesthetics identity and social functions within a culture will not be possible without language. He posits that,

cultural expression is incomplete without language. As a means of communicating values, beliefs and customs, language has an important social function which is to foster feelings of group identity and solidarity. It is a means by which culture and its traditions as well as shared values may be conveyed and preserved. Language is fundamental to cultural identity; it is a defining feature of a person's identity contributing to how they see themselves and how other individuals or groups see and define them. (pp. 101-102)

Ekom's position on language and culture confirms the view that for culture to thrive, language must serve as its vehicle. Within the context of this argument, one would have expected that the contestants in GMB delivered their presentations in local languages. However, the hegemonic presence of the English language as the lingua franca, allows it to dominate all the presentations, including 
the verdicts of the judges. Occasionally, the contestants punctuated their performances with a few sentences in their local languages. The challenge here is the heterogeneity of languages and dialects within the country, which makes it impossible for most people to understand one another. Consequently, the intricate blending of local wisdom, contained in proverbs, with idiomatic expressions that make indigenous dialects beautiful, is lost through the use of a second language -English- that many contestants struggle to speak.

Even more worrying is the fact that there are many expressions in local languages that do not lend themselves easily to English translation. Consequently, the essence of contestants' messages would often be lost, because they are unable to find the right words. Unfortunately, as Mahadi and Jafari (2012) have argued, "words are the most significant tools of cultural symbols" (p.232) hence the need for the contestants to have used local dialects because "particular languages are associated historically with particular cultures; the languages provide the key to the associated cultures," (p.234). It is against the seeming need to encourage the teaching of local language that in her answer to a question asked by one of the judges on how Poka, the Upper East representative, in an answer to a question during the $2013 \mathrm{GMB}$, encouraged parents to teach their children their indigenous language because it preserves Ghanaian culture, depicts where they come from and who they are as specific ethnic groups.

\section{Conclusion}

Berger (1989) argues that "the mass media are powerful in shaping attitudes, beliefs and cultural behaviour"(pp. 152-153). The production and transmission of GMB are intended to serve not only as a repository of Ghana's intangible culture, but also as a means of shaping the attitudes of future generations towards their ovarian cultures. In Ghana, in spite of the influences of foreign cultures, traditional forms continue to exert a great deal of influence on people's sense of identity. However, there is a danger of indigenous cultural extinction if conscious efforts are not made to preserve, appreciate and practice these cultures in the future. Despite the 
numerous challenges, GMB is one of the modest moves to offer a platform for the reassessment of Ghana's heterogeneous mix of cultures, and for their sustainability into the future. In this paper, the author has identified the use of traditional names, clothing, music and dance and language as some of

Ghana's traditional cultural aesthetics in Ghana's most beautiful reality television show. The use of these cultural aesthetics and artefacts has the potential to educate all Ghanaians about their culture and the philosophies embedded in them. While acknowledging that the reality show is didactic, it still represents a capitalistic system of cultural hegemony and consumerism that under the veil of cultural syncretism presents itself as a unique mode of preserving indigenous culture and unification in Ghana. 


\section{References}

Abdallah, M. B. (1989). The witch of Mopti. In The fall of Kumbi and other plays. Accra, Ghana: Woeli Publishing Services (pp. 3-41)

Adesi, K. A., \& Odi, C. (2013). The social context of radio drama in Nigeria: A thematic survey of Umukoro's and Inegbe's plays. In D. A. Akoh \& S. E. Ingebe (Eds.). Arts, culture and communication in a postcolony: A Festschrift for Lawrence Olanrele Bamidele (pp.392403). Kent, OH: Alpha Crownes Publishers.

Akuoku, E. (2015, January 18). Ghana's most beautiful 2013. (A. Dennis, interviewer).

Allan, P. M. (1964). The anthropology of music. New York, NY: North Western University Press.

Anyaoku, E. (2007). The condition of Africa: A cramp in the will. A lecture delivered on November 1, 2007, at the University of Cape Coast Auditorium, University of Cape Coast.

Armlor, Q. M. (2008). Ebibidwom in African Christian liturgy: Its status and impact on Methodist Church liturgy in the Fante communities of Ghana. Drumspeak: International Journal of Research in the Humanities, 1(2), 141-167.

Asare, K. (2003, February 15). Our leaders must dress like Ghanaians. The Ghanaian Times, p.6.

Berger, A. (Ed.). (1989). The politics of culture: Feminism and the media. In Political culture and public opinion. New Jersey: Transaction Publishers.

Botchway, D. N. Y. (2007). Redefining education for liberation from western cultural imperialism: A challenge for Ghana in the twenty-first century. In D. E. K. Amenumey (Ed.), Challenges of education in Ghana in the $21^{\text {st }}$ century (pp.217-228). Accra, Ghana: Woeli Publishing.

Botchway, D. N. Y. (2008). When the people decide: Colonialism, social and economic changes and the emergence of modern nationalism in the Gold Coast. Drumspeak: International Journal of Research in the Humanities, 1(2), 168-216.

Cultural Policy, (2004). The cultural policy of Ghana. Accra, Ghana: Anttis.

Dennis, A. (2014). Designing for period plays: Challenges and opportunities for the costumier of Androcles and the lion. International Journal of Music and Performing Arts, 2(1), 25-37.

De Lerma, D. R. (1970). Black music in our culture: Curricular ideas on the subject's materials and problems. Kent, $\mathrm{OH}$ : Kent State University Press.

Ekom, E. R. (2013). Language and identity: The Nigerian perspective. In E. Johnson (Ed.), IBOM cultural offerings: Arts, crafts and performances (pp. 99108). Cape Coast, Ghana: University of Cape Coast Press.

Essel, Q.O., \& Amissah, P. K. R.(2015).Smock fashion culture in Ghana's dress identity. Historical Research Letter, 1, 32-39 
Ferraro, G. (2008). Cultural anthropology: An applied perspective. Belmont, CA: Thomas Wadsworth.

Flolu, J. (2009). Some approaches to teaching culture. In Culture and education: Report of the national conference on culture (NCC) and education at the Elmina beach resort (pp. 59-70) Accra, Ghana: Sub-Saharan Publishers.

Gavor, M., \& Dennis, A. (2013). Evolution and use of patchwork fabric (nsasawa) in Ghana. The Parnassus: University of Uyo Journal of Cultural Research, 9(2), 225-237.

Gharbin, M. (2014, July 13). Personal communication. (A. Dennis, interviewer). Grossberg, L. (1996). History, politics and postmodernism- stuart hall and cultural studies. In D. Morley \& K. Chen (Eds.). Stuart Hall: Critical dialogues in cultural studies (pp.151-173). New York, NY: Routledge,

Gyekye, K. (1996). African cultural values: An introduction. Accra, Ghana: Sankofa Publishing.

Hall, S. (1996). The problem of ideology: Marxism without guarantees. In D. Morley \& K. Chen (Eds.). Stuart Hall: Critical dialogues in cultural studies (pp. 25-46). New York, NY: Routledge,

Kwakye-Opong, R. (2011). Clothing and adornment in the Ga culture: Seventeenth to twenty-first century. (PhD thesis). Kwame Nkrumah University of Science and Technology, Kumasi, Ghana. Retrieved from http://ir.knust.edu.gh/bitstream/123456789/4614/1/Regina\%20 Kwakye-Opong.pdf .

Lurie, A. (1981). The language of clothing. New York, NY: Random House.

Mahadi, T. S. T., \& Jafari, S. (2012). Language and culture. International Journal of Humanities and Social Science, 2 (17), 230-235.

Maison, B. K. (2007). The Indigenous African and contemporary education in Ghana: The challenge of the $21^{\text {st }}$ century. In D. E. K. Amenumey (Ed.), Challenges of education in Ghana in the 21st century (pp. 2745). Accra, Ghana: Woeli Publishin' ${ }^{\mathrm{g}}$.

Mott, W.H. (2004). Globalization: People, perspective and progress. Westport, CO: Praeger Publishers.

Owusu, M. A. S. (2007). The mis- education of the Ghanaian: A critique of the Ghanaian educational system. In D. E. K. Amenumey (Ed.), Challenges of education in Ghana in the 21 $1^{\text {st }}$ century (pp.91-101). Accra, Ghana: Woeli Publishing.

Panopio, I.S. \& Rolda, R. E. (2006). Society and culture: Introduction to sociology and anthropology. Makati, Philippines: Katha Publishing Co. Inc.

Sarpong, D. P. (1974). Ghana in retrospect: Some aspects of Ghanaian culture. Tema, Ghana: Ghana Publishing Corporation.

Schirato, T., and Yell, S. (2000). Communication and culture: An introduction. Sydney, Australia: Allen and Unwin. 
Dennis, A./ Promoting Ghana's traditional cultural aesthetics

Sunday, D. A. (2010). Imbele: The concept and perception of sweetness in Izon aesthetic judgment. The Parnasuss. University of Uyo Journal of Cultural Research, 1 (6), 108-116.

Ufford, I. (2010). Dance in a revolving tradition and modernity. The Parnasuss. University of Uyo Journal of Cultural Research, 1 (6), 117-131. 